DOI: 10.47745/ERJOG.2020.03.02

\title{
BÁNYAI JÓZSEF
}

\section{Egy-két gondolat a vitaindító nyomán}

\section{Some Thoughts regarding the Keynote Article}

\begin{abstract}
The future of the Romanian-Hungarian relationship is particularly topical in the light of the last hundred years. The importance of language skills, the factual presentation of autonomy, our openness to other minority groups, and our own community activism, regardless of election cycles, cannot be overemphasized.
\end{abstract}

Keywords: Transylvania, Romanian-Hungarian relations, autonomy, education, minorities, election cycles

Összefoglaló: A román-magyar viszony jövője, áttekintve az elmúlt száz év időszakát, különösen aktuális. Nem lehet eléggé hangsúlyozni a nyelvtudás fontosságát és az autonómia tényszerű ismertetését, más kisebbségi csoportok felé való nyitásunkat és saját közösségi aktivizmusunkat, választási ciklusoktól függetlenül.

Kulcsszavak: Erdély, román-magyar viszony, autonómia, oktatás, kisebbségek, választási ciklusok

Moldova György valamelyik erdélyi útja alkalmával, helyi emberrel beszélgetve arra terelődött a szó, hogy miként is élünk mi, magyarok, Romániában (1989 előtt). Emberünk egyszerűen és szemléletesen magyarázta helyzetünket a sokak által (általam is) kedvelt írónak (bár ő nem túlságosan elfogult velünk szemben...): 1918 körül a romániai magyarság bekerült egy nagyocska gödörbe. Hamarosan rájött, hogy nincs egyedül: egy hatalmas medve a társa... akivel kötekedni nem tanácsos (az ismert okok miatt).

Nos, a (primitívnek is mondható) párhuzam szemléletes, valós:

- az idők folyamán akkor, amikor igazából senki sem figyelt hazánkra, nagyjából azt tettek a közösséggel, amit akartak (1918-1944);

- amikor számításba is vehették a véleményünket (pl. Párizsban), „kedvünkben jártak", a külföldi döntéshozók felé felmutatva a kisebbségbarát politikát (1944-1948);

- aztán mindenki egyenlő lett és dúlt az internacionalizmus (1948-1977);

- új divat indult, ami megalapozta a XXI. század Romániáját is: nacionálkommunizmus (1977-1989);

- a nagy remények rövid időszaka hamar lepergett (1989-1990);

- átmenet és az EU-csatlakozás időszaka, amikor azt hittük, megváltozott a kicsi világunk (1991-1996; 1996-2010); 


\section{ERDÉLYI JOGÉLET}

- 2010 után, a sepsiszentgyörgyi iskolaper ${ }^{1}$ nyomán rájöhettünk, hogy mit is jelent a medvével együtt élni... és ez a folyamat ma is tart: a hétköznapi sovinizmus gyakran lecsap, akár a központból jövet, akár helyileg (pl. annak a vegyes házasságból származó gyereknek az esetében, akit a Kolozsvári Törvényszék román óvodába küldött).

Amennyiben meg akarunk maradni és előrelépnénk, amit igencsak remélek, tudomásul kell vennünk, hogy lényegében csak magunkra számíthatunk. Bár a magyarországi segítség jelentős, a hétköznapokat nekünk itt kell megélnünk. Terveznünk nem négyéves ciklusra vagy ciklusokra kell, hanem közép- és hosszú távra.

A román nyelv alapos ismerete nélkül nem boldogulunk sem egyénileg, sem közösségként. Az anyanyelvű oktatást erősíteni kell minden eszközzel, de az egyházak bevonásával látom megoldani az államnyelv sokkal jobb elsajátításának lehetőségét (az anyagi források és az emberanyag kezelése stabil kézben kell legyen; bár sokan nem kedvelik azt az intézményt - én is látom sok hibáját... -, de egyelőre jobbat nem tudok találni: saját hálózatunk nincs, az RMDSZ gyenge, nem elég reprezentatív, 1-2 rossz „elem” hamar bajt okoz).

Az autonómia kérdése nagyon idegen elem a román társadalomban, és a többség nem érti, bizalmatlan. Emiatt nem javaslom, hogy hivatalos formában foglalkozzunk vele mindaddig, amíg a többség nem változtat alaposan álláspontján. Ezt a folyamatot nem nekünk kell végeznünk. Ellenben azt a receptet kellene elővennünk, amit hosszú időn keresztül alkalmaztak (-nak ma is) zsidó testvéreink: lojalitás az állam felé, mint állampolgár (ezt elvárják és meg lehet tenni; el lehet és kell mondani „n”-szer, hogy mi vagyunk a haza leghűbb polgárai), és ugyanakkor a hétköznapi autonómia kiépítése (ami nem szól senki ellen, és mindenkinek, még az államnak is jó), minden szinten, minél több embert, közösséget bevonva és érdekeltté téve.

Valószínű, hogy több időbe fog kerülni, de ne ijedjünk meg. Kezdjük el, bátorítsuk társainkat és a közösségeinket (az lehet a megoldása az alapvető gondjainknak; a Barabás-féle hálózatelmélet is ezt támasztja alá).

Ebben a folyamatban nem lenne szabad megfeledkezni a cigányságról: ha mi nem, a többség vonja magához (a mérai példa lehetne a kiindulást jelentő mód: tanulás-taníttatás + közösségi munka).

Egyelőre ennyi fogalmazódott meg bennem. Folytassuk!

1 A sepsiszentgyörgyi Székely Mikó Kollégium államosított épületeinek a visszaszolgáltatását célzó tulajdoni pert az Erdélyi Református Egyházkerület Romániában jogerősen elvesztette. A per részleteiről és a felmerült jogi problémákról lásd: Veress Emőd: Vázlatos megjegyzések a romániai egyházi ingatlanrendezésről, különös tekintettel a Székely Mikó Kollégium ügyére. Pro Minoritate 2020/nyár, 76-94. 